\title{
Plankton carbon budget in a coastal wind-driven upwelling station off A Coruña (NW Iberian Peninsula)
}

\author{
Eva Teira ${ }^{1,2, *}$, Julio Abalde ${ }^{3}$, María Teresa Álvarez-Ossorio ${ }^{4}$, Antonio Bode ${ }^{4}$, \\ Carlos Cariño ${ }^{1}$, Ángeles Cid ${ }^{3}$, Emilio Fernández ${ }^{1}$, Nicolás González ${ }^{4}$, \\ Jorge Lorenzo ${ }^{4}$, Joaquín Valencia ${ }^{3}$, Manuel Varela ${ }^{4}$ \\ ${ }^{1}$ Universidad de Vigo, Facultad de Ciencias, 36200 Vigo, Spain \\ ${ }^{2}$ Royal Netherlands Institute for Sea Research (NIOZ), PO Box 59, 1790 AB, Den Burg, Texel, Netherlands \\ ${ }^{3}$ Universidad de A Coruña, Facultad de Ciencias, 15071 A Coruña, Spain \\ ${ }^{4}$ Instituto Español de Oceanografía, Centro Costero de A Coruña, 15080 A Coruña, Spain
}

\begin{abstract}
Seasonal variations in phytoplankton and bacterial biomass along with rates of primary production, dissolved organic carbon (DOC) release, bacterial production, dark respiration and vertical particle flux were determined from December 1998 to September 1999 at a coastal station off A Coruña (NW Spain) affected by episodes of wind-driven upwelling. Maximum phytoplankton biomass and production was associated with upwelling events. Bacterial biomass remained relatively constant throughout the study and was always lower than phytoplankton biomass. Depth-integrated rates of DOC release, which ranged from 0.2 to $3.1 \mathrm{~g} \mathrm{C} \mathrm{m}^{-2} \mathrm{~d}^{-1}$, were not a constant fraction of the total amount of carbon incorporated by primary producers. On average, DOC release accounted for $37 \pm 7 \%$ of total primary production, and the highest values were measured during low-productivity periods. The supply of DOC by microplankton was globally sufficient to support the estimated bacterial activity, although a temporal shift between DOC release and bacterial consumption was observed. Primary production exceeded respiration during most of the seasonal study, with production/respiration ratios ranging from 1 to 7 . The annual averaged daily net community production was $253( \pm 105) \mathrm{mmol} \mathrm{O}_{2} \mathrm{~m}^{-2} \mathrm{~d}^{-1}$. The amount of particulate organic carbon exported from the euphotic layer was 1 to $86 \%$ of total primary production. The results of this study indicate that the coastal system is autotrophic, and suggest that most of the organic matter produced photosynthetically was channelled through the microbial food web.
\end{abstract}

KEY WORDS: Plankton carbon biomass - Primary production - Dissolved organic carbon release · Bacterial production - Microbial community respiration - Sinking carbon · NW Iberian Peninsula

Resale or republication not permitted without written consent of the publisher

\section{INTRODUCTION}

Microbial food-web processes may influence the export and sequestration of carbon in the oceans (Legendre \& Le Fèvre 1995). The energy supplied by primary producers to higher trophic levels is transferred through 2 main pathways: (1) the herbivorous food chain from large phytoplankton to metazooplankton, and (2) the microbial food web, in which most picoplankton carbon is transferred via dissolved organic matter to bacteria and protozoans, and only a minor part of the photosynthetically produced carbon is available to higher trophic levels.
Bacterial production is the key process responsible for the flux of dissolved organic matter through the microbial food web and, consequently, the estimation of bacterial production is crucial to establishing the importance of microbial food webs in marine ecosystems (Ducklow 2000). Large-scale geographic and vertical distributions of phytoplankton and bacterioplankton suggest a general dependence of bacteria on phytoplankton (Cole et al. 1988, Ducklow 1999, 2000, Hoppe et al. 2002). It has been commonly reported that, on average, about $50 \%$ of primary production flows to bacterioplankton via dissolved organic carbon (e.g. Ducklow 2000, Nagata 2000). However, the sig- 
nificance of bacterioplankton production and the associated microbial food web as a source of particulate organic carbon to metazoan food webs is a matter of controversy (Malone \& Ducklow 1990, review: Williams 2000), as it is thought this flow might be larger than previously assumed (Uitto et al. 1997). A recent study has shown that, in natural waters, the contribution of heterotrophic bacteria to plankton biomass and metabolism varies systematically across a trophic gradient, being higher in oligotrophic than in eutrophic waters (Biddanda et al. 2001). In this connection, Shiah et al. (2001) suggested that a high ratio between bacterial metabolism and primary production may imply less organic matter available for higher trophic levels and/or for export to the deep ocean and sediments.

The coast of A Coruña (NW Spain) is a region of high primary production influenced by the seasonal upwelling of deep nutrient-rich waters (e.g. Bode \& Varela 1994, Casas 1995, Bode et al. 1998a). The upwelling occurs between March and October in the form of discrete events driven by northerly winds, (Fraga 1981, Blanton et al. 1984), giving rise to a period of high primary production that allows important pelagic fishing on the shelf (Tenore et al. 1995). It is also known that large accumulations of organic matter occur in shallow areas of the continental shelf, particularly near the more productive rías (Álvarez-Salgado et al. 1997).

Data on the functioning of the microbial system in Galician on-shelf waters off the rías is still scarce. Bacterial abundance and activity has only been estimated in a few cases (Bode \& Varela 1994, Tenore et al. 1995, Barquero 1999, Barbosa et al. 2001), whereas more data are available on phytoplankton biomass and primary production (e.g. Estrada 1984, Casas 1995, Bode et al. 1996, Castro et al. 1997, Joint et al. 2001, Teira et al. 2001b). The present investigation was conceived with the aim of assessing the significance of microbial- mediated carbon fluxes in relation to the herbivorous food chain in a coastal pelagic environment affected by upwelling events, through the concurrent measurement of the biomass and production rates of the main microbial compartments (bacteria and phytoplankton), dissolved organic carbon production, microbial community respiration and vertical particle flux, on a seasonal basis.

\section{MATERIALS AND METHODS}

Sampling. Water-column measurements were conducted at 2 stations off A Coruña (NW Spain) (Fig. 1) at approximately monthly intervals between December 1998 and September 1999. Temperature, salinity, photosynthetically available radiation (PAR), and in situ fluorescence were measured at both stations with a conductivity, temperature and depth profiler (CTD) Seabird SBE-25, equipped with a LiCOR spherical sensor and an in vivo fluorometer.

Water samples were collected with Niskin bottles at Stn 2 (total depth $=79 \mathrm{~m}$ ) from irradiance levels of 100, $50,25,10$ and $1 \%$ surface irradiance (PAR) for the determination of chlorophyll $a(\operatorname{chl} a)$ and particulate organic carbon (POC) concentrations, bacterial biomass (BB), and rates of POC, dissolved organic carbon (DOC), and bacterial production (BP) and microbial community respiration (CR). An additional water sample was collected from $70 \mathrm{~m}$ depth for determination of chl $a$ and POC concentration, and for bacterial enumeration and production. In addition, a multitrapcollector system was deployed at $50 \mathrm{~m}$ and anchored to the sea floor at Stn 2T (depth $63 \mathrm{~m}$ ) for $24 \mathrm{~h}$ to collect sedimented particles. For logistic reasons, the trap had to be located 1 nautical mile away from Stn 2. The trap system, described by Knauer et al. (1979), consisted of 4 transparent Plexiglas collection cylinders of $6 \mathrm{~cm}$



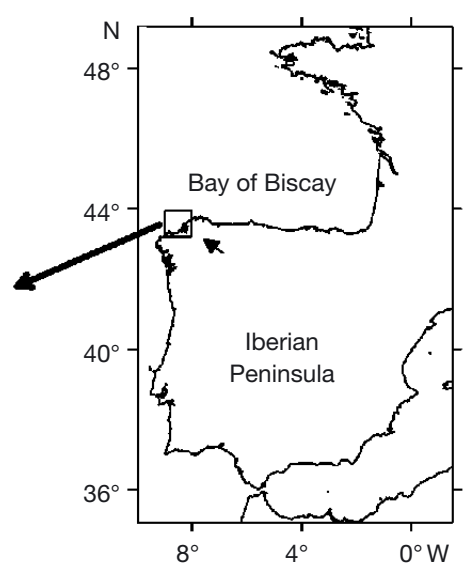

Fig. 1. Location of sampling stations 2 and $2 \mathrm{~T}$ from December 1998 to September 1999 
diameter each. Prior to deployment, the cylinders were filled with a saline solution to prevent the escape of particles from the traps. Immediately after recovery, aliquots of the material collected by the traps were filtered through Whatman GF/F filters for determination of chl $a$ and POC concentration.

Upwelling index. Daily offshore upwelling indices (Iw) at $43^{\circ} 22^{\prime} \mathrm{N}, 8^{\circ} 25^{\prime} \mathrm{W}$ were obtained from local wind measurements made every $6 \mathrm{~h}$ by the Centro Metorológico Zonal de A Coruña (Bakun 1973, Lavin et al. 2000).

Chlorophyll $a$ and POC concentration. Seawater samples (100 to $250 \mathrm{ml}$ ) were filtered through $25 \mathrm{~mm}$ glass fibre-filters (GF/F) Millipore Type F. Filters were immediately frozen 1 to $2 \mathrm{~h}$ before pigment extraction in $10 \mathrm{ml}$ of $90 \%$ acetone for 8 to $12 \mathrm{~h}$ at $-10^{\circ} \mathrm{C}$. Chlorophyll a concentration was then determined with a Turner Designs C10-005R fluorometer calibrated with a chl a extract from a culture of Isochrysis galbana. Phytoplankton biomass (PhB) was calculated from chl a concentration using a conservative conversion factor C/chl a of 50 (see Longhurst 1995 and Barlow et al. 1998).

Particulate carbon concentration was determined in $500 \mathrm{ml}$ of seawater filtered through Whatman GF/F filters which were stored frozen $\left(-20^{\circ} \mathrm{C}\right)$ until analysis in a Perkin Elmer CHN analyser.

Primary production of POC. Three $250 \mathrm{ml}$ acidcleaned Pyrex bottles (2 transparent, 1 dark) were filled with seawater from 5 depths corresponding to optical depths ranging from 100 to $1 \%$ of surface irradiance levels. Each bottle was inoculated with $148 \mathrm{kBq}$ $\left(4 \mu \mathrm{Ci}\right.$ ) of $\mathrm{NaH}^{14} \mathrm{CO}_{3}$ and then incubated ashore for 2 to $3 \mathrm{~h}$ in an incubator which simulated the irradiance experienced by the cells at the original sampling depths. Incubation bottles were cooled by pumping surface seawater. After the incubation period, samples were filtered at very low vacuum pressure (<50 $\mathrm{mm} \mathrm{Hg})$ through the same type of filters as used for chl a determinations. In order to remove the dissolved inorganic ${ }^{14} \mathrm{C}$, filters were acidified with $10 \% \mathrm{HCl}$ for 8 to $12 \mathrm{~h}$. Finally, $3.5 \mathrm{ml}$ of scintillation cocktail was added to each filter and radioactivity was measured with a LKB $\beta$-scintillation counter. Quenching corrections were made using an external standard.

Daily rates of POC were calculated from hourly rates utilising the equation of Straskraba \& Gnauck (1985), which rendered average daylight lengths from 7 to $13 \mathrm{~h}$ during the sampling period.

DOC release by microbial populations. Four $30 \mathrm{ml}$ seawater samples were collected from 3 selected depths, inoculated with $740 \mathrm{Kbq}(20 \mu \mathrm{Ci})$ of $\mathrm{NaH}^{14} \mathrm{CO}_{3}$ and kept in the same incubator as for POC production incubations for $2 \mathrm{~h}$ in order to minimise concurrent bacterial consumption of recently released DOC dur- ing the incubation period (see review by Fogg 1983). Two $7 \mathrm{ml}$ subsamples were drawn from each bottle and filtered through $0.2 \mu \mathrm{m}$ polycarbonate membrane filters. Labelled dissolved inorganic carbon was removed by acidifying the filtrates with $40 \mu \mathrm{l}$ of $50 \% \mathrm{HCl}$ and bubbling with $\mathrm{CO}_{2}$-free air for $12 \mathrm{~h}$. Scintillation cocktail was then added to the filtrates. Duplicate blank tests were run in parallel by inoculating and immediately processing $0.2 \mu \mathrm{m}$-filtered seawater in the same way as described above. The variation coefficient (SD/mean) for the measurements of DOC-release was $26 \pm 3 \%$ (mean \pm SE). Daily euphotic depth-integrated DOC-release rates were calculated from hourly rates considering (1) a constant DOC-release rate during the light (DOC light) period only and (2) over $24 \mathrm{~h}\left(\mathrm{DOC}_{24 \mathrm{~h}}\right)$.

The sum of POC production and DOC release rates gave a value close to gross primary production of organic carbon (GPPc). We checked that the incubation time for POC production and DOC release was short enough to minimise the loss of radiolabel due to respiratory processes.

Bacterial abundance. Bacterial abundance was measured by direct microscopy on black polycarbonate filters (Porter \& Feig 1980). Samples were fixed with glutaraldehyde $(2 \% \mathrm{v} / \mathrm{v})$ and kept in the dark at $4{ }^{\circ} \mathrm{C}$ until further processing. Subsamples $(10 \mathrm{ml})$ were taken and stained with 4'-6-diamidino-2-phenylindole (DAPI, final concentration $2.5 \mu \mathrm{g} \mathrm{ml}^{-1}$ ) for $5 \mathrm{~min}$ in the dark, and then filtered through $0.2 \mu \mathrm{m}, 25 \mathrm{~mm}$ diameter polycarbonate filters under low vacuum pressure ( $<150 \mathrm{~mm} \mathrm{Hg}$ ). The filters were assembled on a slide with low fluorescence oil, and stored frozen until visualisation. Bacterial enumeration was performed using ultraviolet light in an epifluorescence microscope (Olympus BH-2). Cell abundance was transformed to bacterial carbon biomass (BB) using the empirical equation by Norland et al. (1987):

$$
\mathrm{C}=0.09 \mathrm{BV}^{0.9}
$$

where $\mathrm{C}$ is the carbon content $\left(\mathrm{pgC} \mathrm{cell}^{-1}\right)$ and $\mathrm{BV}$ the bacterial biovolume $\left(\mu^{3}\right.$ cell $\left.^{-1}\right)$. Bacterial biovolume was computed from measurements of bacterial cell dimensions using a graduated bar coupled to the microscope eyepiece. Cocci and rods were considered as spheres and cylinders, respectively. The mean $( \pm \mathrm{SD})$ bacterial biovolume obtained in this study was

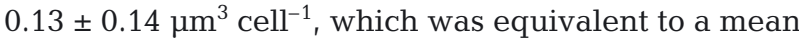
$( \pm \mathrm{SD})$ bacterial carbon content of $14 \pm 14 \mathrm{fg} \mathrm{C} \mathrm{cell}^{-1}$.

Bacterial production. Bacterial production was estimated from $\left[{ }^{3} \mathrm{H}\right]$-leucine incorporation rates into proteins following the method of Kirchman (1993), but substituting centrifugation for the final filtration of bacteria (Smith \& Azam 1992). Four $1 \mathrm{ml}$ aliquots of water samples from each depth were inoculated with ${ }^{3} \mathrm{H}$-leucine hot-cold mixture; $10 \%$ hot plus $90 \%$ cold) 
to a final concentration of $150 \mathrm{nM}$ and incubated at room temperature for 30 to $45 \mathrm{~min}$ in $1.5 \mathrm{ml}$ Eppendorf vials. Two $1 \mathrm{ml}$ controls killed with trichloroacetic acid (TCA, $5 \% \mathrm{w} / \mathrm{v}$ ) were incubated for each depth. $\left[{ }^{3} \mathrm{H}\right]$-leucine incorporation rates were corrected for the effect of incubation temperature using the results of an additional set of experiments (see details in Valencia et al. 2003). Incubations were terminated by the addition of $5 \%$ TCA to the incubation vials. Dissolved leucine was removed from the incubation vials by repeated washing with $5 \%$ TCA and successive centrifugation (16 $060 \times g, 10 \mathrm{~min})$. Scintillation cocktail was added to the vials and radioactivity was measured on an LKB $\beta$-scintillation counter. Conversion factors for leucine incorporation and cell growth or carbon production were determined experimentally in 7 experiments following the procedure of Kirchman \& Ducklow (1993). For each experiment, $200 \mathrm{ml}$ of seawater was added to $800 \mathrm{ml}$ of $0.2 \mu \mathrm{m}$-filtered seawater and incubated at room temperature for $50 \mathrm{~h}$. Every 3 to $4 \mathrm{~h}$, aliquots of this culture were removed for the determination of bacterial abundance and leucine incorporation rates by the described procedures. The mean $( \pm \mathrm{SD}, \mathrm{n}=6)$ conversion factor was $3.6 \pm 1.8 \times 10^{8}$ cell $(\mathrm{nmol}$ leucine $)^{-1}$. Daily rates of BP were calculated assuming that BP was constant during the day, as some studies have suggested that daily variations in BP in coastal zones are not very pronounced (e.g. Gasol et al. 1998).

Bacterial growth efficiency (BGE) was estimated from water temperature using the empirical model of Rivkin \& Legendre (2002). Bacterial carbon demand (BCD) was calculated from $\mathrm{BP}$ and $\mathrm{BGE}$ (BCD = $\mathrm{BP} / \mathrm{BGE}$ ). Bacterial respiration (BR) was estimated as the difference between BCD and BP. The averaged bacterial growth efficiency obtained was 0.22 , which is close, but slightly lower, than the mean value $(0.27)$ given by del Giorgio \& Cole (2000) for coastal areas.

$\mathrm{O}_{2}$ production and respiration rates. Oxygen production and consumption rates were determined by light- and dark-bottle incubations at 4 selected depths. We carefully filled 4 light and 8 dark, $125 \mathrm{~cm}^{3}$, gravimetrically calibrated, borosilicate bottles filled from each depth, using silicone tubing, overflow $>250 \mathrm{~cm}^{3}$. An initial set of 4 dark bottles was fixed immediately for initial oxygen concentration, the remainder being kept under a light-dark diel cycle in the same incubator as for ${ }^{14} \mathrm{C}$ incubations. Fixing and storage procedures, reagents and standardisation followed the recommendations of Grasshoff et al. (1983). Dissolved oxygen concentration was measured through automated precision Winkler titration performed with a Metrohm 721 DMS Titrino, using a potentiometric endpoint detector as described in Serret et al. (1999). Net community production (NCP) and community respiration (CR) were estimated as the change in oxygen con- centration in the light and dark bottles, respectively, after incubation. Gross oxygen production (GPPo) was estimated as the sum of NCP and CR. CR was converted into $C$ units using a respiration quotient (RQ) of 1.

Mesozooplankton biomass. Zooplankton was sampled at Stn 2 from the surface to ca. $70 \mathrm{~m}$ depth using double oblique hauls with a $\mathrm{WP}_{2}$ plankton net $(200 \mu \mathrm{m}$ mesh-size). Zooplankton biomass was estimated as dry weight of non-preserved aliquots filtered through pre-weighed Whatman GF/C filters which were later dried at $60^{\circ} \mathrm{C}$ for $48 \mathrm{~h}$. Dry weight was converted to carbon following the method of Bode et al. (1998b).

Euphotic-zone integration. Euphotic-zone-integrated values of the different biological variables were obtained by trapezoidal integration of the volumetric data down to the depth of $1 \%$ surface irradiance. Euphotic zone depth ranged from 30 to $40 \mathrm{~m}$.

\section{RESULTS}

\section{Hydrographic conditions}

The distribution of the daily offshore upwelling indices during the sampling period (Fig. 2A) was characterised by a predominance of upwelling-favourable conditions (as inferred by positive Iw values) from February to September, although the wind stress was highly variable and periods of strong northerly winds alternated with periods of low or negative Iw.

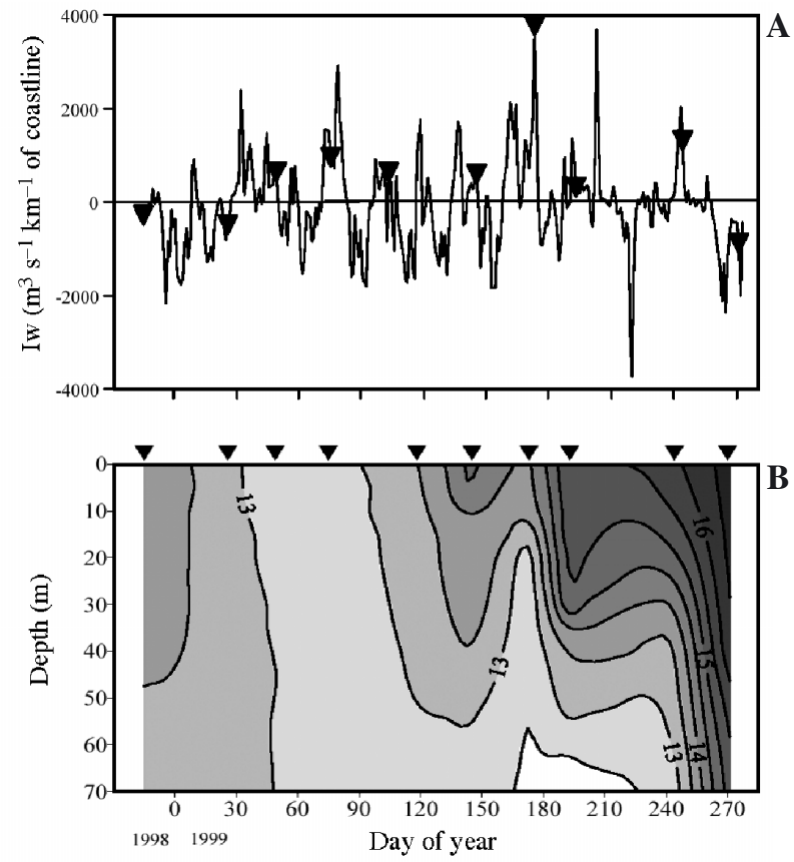

Fig. 2. (A) Distribution of daily offshore upwelling index Iw and (B) vertical distribution of temperature $\left({ }^{\circ} \mathrm{C}\right)$ throughout sampling period at Stn 2. $\boldsymbol{\nabla}$ indicate sampling dates 
The thermohaline variability throughout the sampling period was mainly controlled by the seasonal thermal cycle, associated with changes in solar radiation characteristic of this temperate environment and by the presence of upwelling episodes during late spring and summer (Fig. 2B). It is important to stress that the temporal interval of sampling may not have been ideal for adequately characterising this highly dynamic upwelling system. The water column was thermally homogeneous during winter and, to a lesser extent, during autumn, whereas during spring and summer thermal stratification was always present. The seasonal and spatial variability in density closely paralleled that in temperature. The main upwelling episode occurred in June 1999 (Day 173), when $13^{\circ} \mathrm{C}$ water reached 20 to $30 \mathrm{~m}$ depth, although a less intense pulse was also detected at the end of August 1999 (Day 244), as reflected by the slight uplift in the 13 to $15^{\circ} \mathrm{C}$ isotherms (Fig. 2B).

\section{Phytoplankton biomass and primary production}

Phytoplankton biomass (Fig. 3A), estimated from chlorophyll a concentration, was maximum between the surface and $10 \mathrm{~m}$ depth during the whole sampling period. The highest values $\left(>12 \mathrm{mg} \mathrm{chl} \mathrm{a} \mathrm{m}{ }^{-3}\right.$ ) were measured in June 1999 (Day 173), i.e. were related to the main upwelling event. There was also a phytoplankton bloom in February 1999 (Day 48), when high

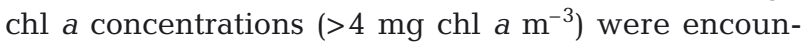
tered in surface waters. The lowest values $(<0.5 \mathrm{mg}$

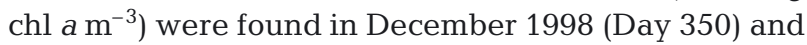
in January and March 1999 (Days 26 and 75, respectively). Water-column (0 to $70 \mathrm{~m}$ ) integrated chl a con-

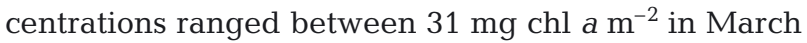
1999 and $270 \mathrm{mg} \mathrm{chl} \mathrm{a} \mathrm{m}^{-2}$ during the main upwelling episode in June (Table 1).

Table 1. Summary of mass variables integrated for entire water colum (0 to $70 \mathrm{~m}$ ), expressed in $\mathrm{mg} \mathrm{C} \mathrm{m}^{-2}$ (chlorophyll a concentration expressed in $\mathrm{mg} \mathrm{chl} \mathrm{a} \mathrm{m}^{-2}$ ). PhB: phytoplankton biomass; BB: bacterial biomass; POC: particulate organic carbon.

-: no data (see 'Materials and methods' for calculations)

\begin{tabular}{|lrrcrc|}
\hline Month & $\begin{array}{c}\text { Chl a } \\
\text { conc. }\end{array}$ & PhB & BB & $\begin{array}{r}\text { POC } \\
\text { conc. }\end{array}$ & $\begin{array}{c}\text { Zooplankton } \\
\text { biomass }\end{array}$ \\
\hline Dec 1998 & 45 & 2237 & 423 & 7800 & 203 \\
Feb 1999 & 110 & 5513 & 596 & 5271 & 483 \\
Mar 1999 & 31 & 1532 & 409 & - & 533 \\
May 1999 & 94 & 4703 & 430 & 4963 & 870 \\
Jun 1999 & 270 & 13496 & 477 & 7220 & 467 \\
Jul 1999 & 53 & 2657 & 368 & 5729 & 1008 \\
Aug 1999 & 58 & 2925 & 445 & 6067 & 684 \\
Sep 1999 & 68 & 3405 & - & 6607 & 1576 \\
\hline
\end{tabular}
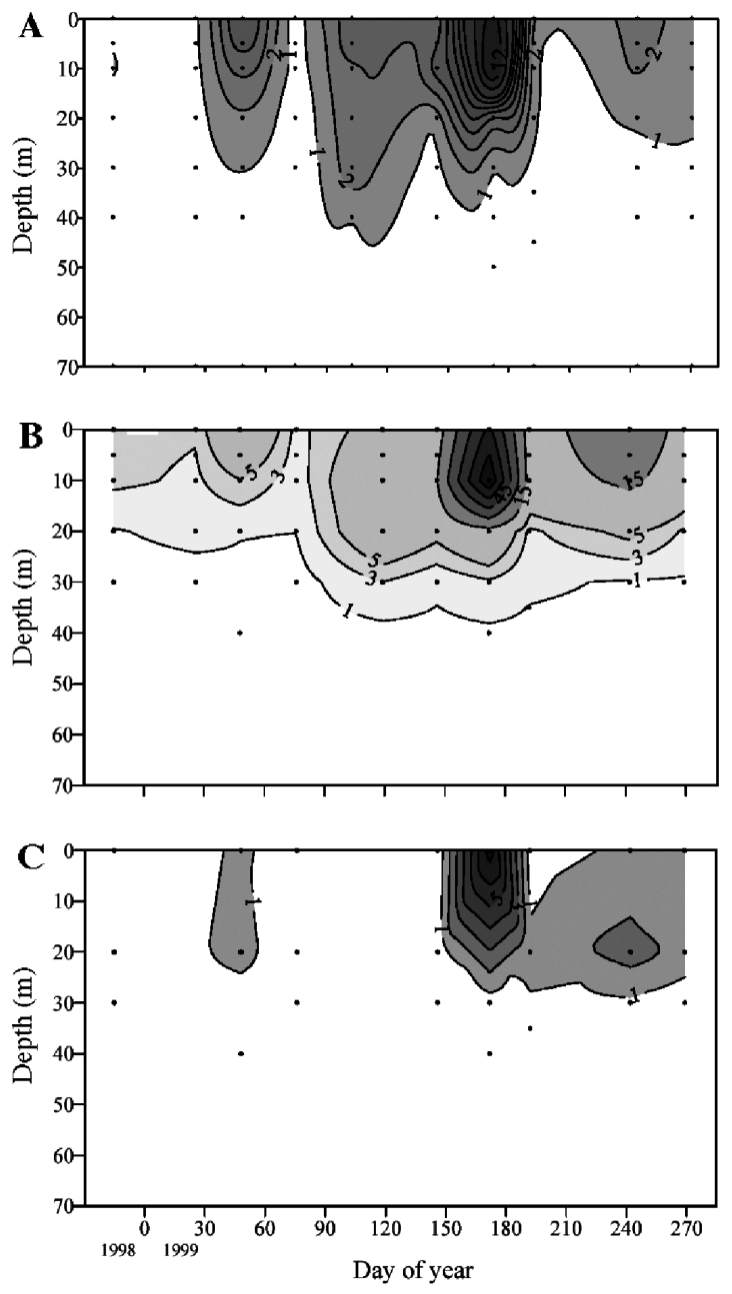

Fig. 3. Vertical distribution of (A) chlorophyll a $\left(\mathrm{mg} \mathrm{m}^{-3}\right)$, (B) particulate organic carbon production $\left(\mathrm{mg} \mathrm{m}^{-3} \mathrm{~h}^{-1}\right)$ and (C) dissolved organic carbon release $\left(\mathrm{mg} \mathrm{m}^{-3} \mathrm{~h}^{-1}\right)$ throughout sampling period

Seasonal variability in POC production rates (Fig. 3B) closely followed that in phytoplankton biomass. The highest rates occurred in June 1999 (Day 173), when values up to $88 \mathrm{mg} \mathrm{C} \mathrm{m}^{-3} \mathrm{~h}^{-1}$ were measured in subsurface waters $(10 \mathrm{~m})$. The lowest rates were found in March (Day 75) 1999, when values ranging between 0.1 and 2.3 $\mathrm{mgC} \mathrm{m}{ }^{-3} \mathrm{~h}^{-1}$ were found. Euphotic-depth- integrated POC production rates during the sampling period varied from 38 to $957 \mathrm{mg} \mathrm{C} \mathrm{m}^{-2} \mathrm{~h}^{-1}$. The corresponding daily integrated rates ranged from ca. 0.4 in March (Day 75) 1999, to >12 $\mathrm{g} \mathrm{C} \mathrm{m}^{-2} \mathrm{~d}^{-1}$ in June (Day 173) 1999.

Rates of DOC release (Fig. 3C) ranged from 0.1 to $7.6 \mathrm{mg} \mathrm{C} \mathrm{m}^{-3} \mathrm{~h}^{-1}$, which represents between 4 and $57 \%$ of gross primary production (GPPc), and showed a similar distribution pattern to that of POC production rates. The relative contribution of DOC to GPPC was lower during early summer than during the less productive periods. Daily euphotic-depth-integrated DOC 
Table 2. Summary of flux variables integrated over photic zone (see 'Materials and methods' for calculations). GPPc: gross primary production, $\mathrm{DOC}_{\text {light, }}$ $\mathrm{DOC}_{24 \mathrm{~h}}$ : dissolved organic carbon release during light period only and during light plus dark periods, respectively; BP: bacterial production; BCD: bacterial carbon demand; CR: community respiration; SC: sinking carbon; GPPo, NCP: gross primary and net community production measured with dark-light $\mathrm{O}_{2}$ method. All variables expressed in $\mathrm{mgC} \mathrm{m}^{-2} \mathrm{~d}^{-1}$, except GPPo and NCP $\left(\mathrm{mmol} \mathrm{O}_{2} \mathrm{~m}^{-2} \mathrm{~d}^{-1}\right)$

\begin{tabular}{|lrrrrrrrrr|}
\hline Month & GPPC & GPPo & NCP & DOC $_{\text {light }}$ & DOC $_{24 \mathrm{~h}}$ & BP & BCD & CR & SC \\
\hline Dec 1998 & 498 & 13 & 8 & 49 & 168 & 14 & 83 & 70 & 21 \\
Feb 1999 & 1487 & 279 & 215 & 332 & 886 & 44 & 180 & 779 & 78 \\
Mar 1999 & 519 & 164 & 74 & 141 & 338 & 21 & 87 & 470 & 444 \\
May 1999 & 4342 & 358 & 282 & 179 & 331 & 429 & 1914 & 913 & 197 \\
Jun 1999 & 14134 & 1248 & 983 & 1699 & 3137 & 138 & 590 & 3174 & 111 \\
Jul 1999 & 2837 & 368 & 295 & 429 & 792 & 47 & 215 & 874 & 206 \\
Aug 1999 & 4313 & 257 & 177 & 581 & 1267 & 138 & 644 & 949 & 223 \\
Sep 1999 & 2053 & 106 & -11 & 378 & 1008 & 364 & 1814 & 1410 & 168 \\
\hline
\end{tabular}

\section{Bacterial biomass and production}

The vertical distribution of BB and BP along the sampling period has been described in detail by Valencia et al. (2003). Enhanced bacterial production rate resulted from higher specific bacterial activities rather than from increases in bacterial abundance.

Euphotic-depth-integrated values of $\mathrm{BB}$ and BP are given in Tables 1 and 2, respectively. Whereas $\mathrm{BB}$ remained almost constant during the sampling period, BP varied between 14 and 429 $\mathrm{mgC} \mathrm{m} \mathrm{m}^{-2} \mathrm{~d}^{-1}$, with minimum rates during the winter period and in July 1999. The BP to GPPC ratio averaged 6\% (Table 3) and was very similar to the

release rates, calculated for a constant DOC release rate during the light period only $\left(\mathrm{DOC}_{\text {light }}\right)$ and for a $24 \mathrm{~h}$ period $\left(\mathrm{DOC}_{24 \mathrm{~h}}\right.$ ), ranged from 49 to 1699 and from 168 to $3137 \mathrm{mg} \mathrm{C} \mathrm{m}^{-2} \mathrm{~d}^{-1}$, respectively (Table 2), thus contributing, from 4 to 27 and from 8 to $65 \%$ to the daily GPPc, respectively (Table 3).

We evaluated the relationship between DOC release and POC production following the same procedure as Teira et al. (2001a,b). A statistically significant log-log linear relationship was found between the rates of DOC release and POC production (Fig. 4). The corresponding equations obtained by the ordinary least- squares (OLS) method (Model I) were: $\log [\mathrm{DOC}]=0.43 \mathrm{log}$ $[\mathrm{POC}]-0.30, \mathrm{r}^{2}=0.52, \mathrm{p}<0.0001$; and $\log [\mathrm{DOC}]=$ $0.69 \log [\mathrm{POC}]-0.12, \mathrm{r}^{2}=0.59, \mathrm{p}=0.026$, for volumetric and integrated data, respectively. Major axis regression (Model II) was also applied, as error is inherent to both $x$ and $y$ variables, and the resulting slopes were 0.58 and 0.91 , respectively. DOC release increased as a function of particulate production; however, only 52 and $59 \%$ of the observed variability in DOC release rates was explained by the volumetric and integrated rates of POC production, respectively. daily ratio between $\mathrm{BP}$ and net primary production measured by Barbosa et al. (2001) in a recently upwelled water mass at the NW Iberian margin. Daily euphotic-depth-integrated BCD (calculated using an estimated BGE that varied between 0.20 [September 1999] and 0.24 [February and March 1999]: see 'Materials and methods' section for further details) ranged from 83 to $1914 \mathrm{mgC} \mathrm{m}^{-2} \mathrm{~d}^{-1}$ (Table 2) and represented, on average $( \pm \mathrm{SE}), 26 \pm$ $9 \%$ of GPPC and $118 \pm 64 \%$ of daily DOC $_{24 \mathrm{~h}}$ (Table 3). BCD only exceeded integrated $\mathrm{DOC}_{24 \mathrm{~h}}$ (Table 2) during May and September 1999, indicating that by that time DOC release was not sufficient to fulfil bacterial metabolism. Assuming that DOC release took place only during the light period, BCD globally exceeded DOC release during the sampling period (Table 3).

We did not find a statistically significant log-log linear relationship between volumetric BCD and DOC release rates (Fig. 5). The following Model I regression equation was obtained using the whole volumetric dataset: $\log [\mathrm{BCD}]=0.52 \log [\mathrm{DOC}]-0.35, \mathrm{r}^{2}=0.13$, $\mathrm{p}=0.0973, \mathrm{n}=23$. When all the data above the line

Table 3. Ratios (\%) between variables in Tables 1 and 2. BGE: bacterial growth efficiency; other abbreviations as in Table 2. (See 'Materials and methods' for calculations). -: no data

\begin{tabular}{|c|c|c|c|c|c|c|c|c|c|c|c|c|}
\hline Month & $\mathrm{BB} / \mathrm{PhB}$ & $\mathrm{PhB} / \mathrm{POC}$ & $\mathrm{BB} / \mathrm{POC}$ & $\begin{array}{l}\text { DOC }_{\text {light }} / \\
\text { GPPC }\end{array}$ & $\begin{array}{c}\mathrm{DOC}_{24 \mathrm{~h}} / \\
\mathrm{GPPC}^{-}\end{array}$ & $\begin{array}{l}\text { Estimated } \\
\text { BGE }\end{array}$ & $\mathrm{BP} / \mathrm{GPPc}$ & BCD/GPPC & $\begin{array}{c}\text { BCD/ } \\
\text { DOC }_{\text {light }}\end{array}$ & $\begin{array}{c}\text { BCD/ } \\
\text { DOC }_{24 h}\end{array}$ & CR/GPPC & $\mathrm{SC} / \mathrm{GPPC}$ \\
\hline Dec 1998 & 19 & 29 & 5 & 10 & 34 & 23 & 3 & 17 & 170 & 47 & 14 & 4 \\
\hline Feb 1999 & 11 & 105 & 11 & 22 & 60 & 24 & 3 & 12 & 54 & 20 & 52 & 5 \\
\hline Mar 1999 & 27 & - & - & 27 & 65 & 24 & 4 & 17 & 62 & 26 & 91 & 86 \\
\hline May 1999 & 9 & 95 & 9 & 4 & 8 & 22 & 10 & 44 & 1069 & 578 & 21 & 5 \\
\hline Jun 1999 & 4 & 187 & 7 & 12 & 22 & 23 & 1 & 4 & 35 & 19 & 22 & 1 \\
\hline Jul 1999 & 14 & 46 & 6 & 15 & 28 & 22 & 2 & 8 & 50 & 27 & 31 & 7 \\
\hline Aug 1999 & 15 & 48 & 7 & 13 & 29 & 21 & 3 & 15 & 111 & 51 & 22 & 5 \\
\hline Sep 1999 & - & 52 & - & 18 & 50 & 20 & 18 & 88 & 480 & 180 & 69 & 8 \\
\hline
\end{tabular}



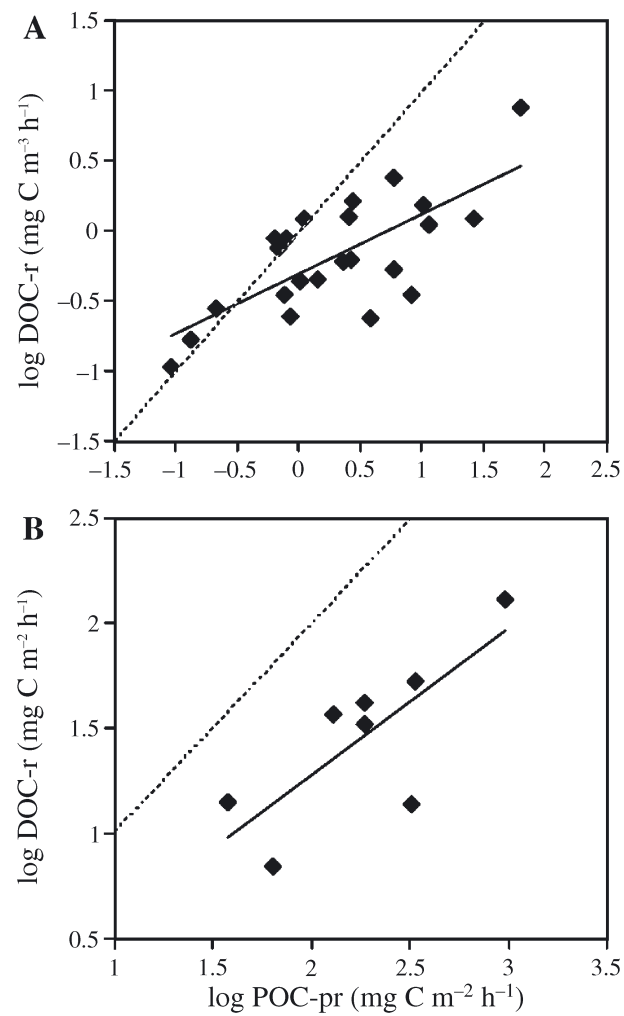

Fig. 4. Log-log relationship between dissolved organic carbon release (DOC-r) and particulate organic carbon production (POC-pr) obtained using (A) volumetric and (B) integrated data. Dashed line: Slope 1. Model I equations of regressions (continuous lines) are $\log [$ DOC-r] $=0.43 \log$ [POC-pr] $-0.30, \mathrm{r}^{2}=0.52, \mathrm{p}<0.0001$; and $\log$ [DOC-r] $=0.69$ $\log$ [POC-pr] $-0.12, \mathrm{r}^{2}=0.59, \mathrm{p}=0.026$, for volumetric and integrated data, respectively

of Slope 1 (i.e. data points corresponding to a BCD exceeding concurrent DOC release) were removed from the dataset (Fig. 5), the corresponding regression line was $\log [B C D]=0.75 \log [D O C]-0.64, r^{2}=0.50$, $\mathrm{p}=0.0031, \mathrm{n}=15$, suggesting that, at this sampling point, recent DOC release was the main carbon source for bacterial metabolism. All the data above Line 1:1 corresponded to the entire depth profile during May and September 1999 and to single depths during December 1998 and August 1999.

\section{POC concentration}

Euphotic-depth-integrated POC concentration varied between 5.0 and $7.8 \mathrm{~g} \mathrm{C} \mathrm{m}^{-2}$, remaining almost constant (from 5.0 to 5.3) between February and May 1999 (Table 1). Highest values were measured in winter 1998 and during the summer phytoplankton bloom in June 1999. On average, phytoplankton and bacterial carbon biomass accounted for only 32 and $8 \%$ of the total POC concentration, respectively (Table 3 ).

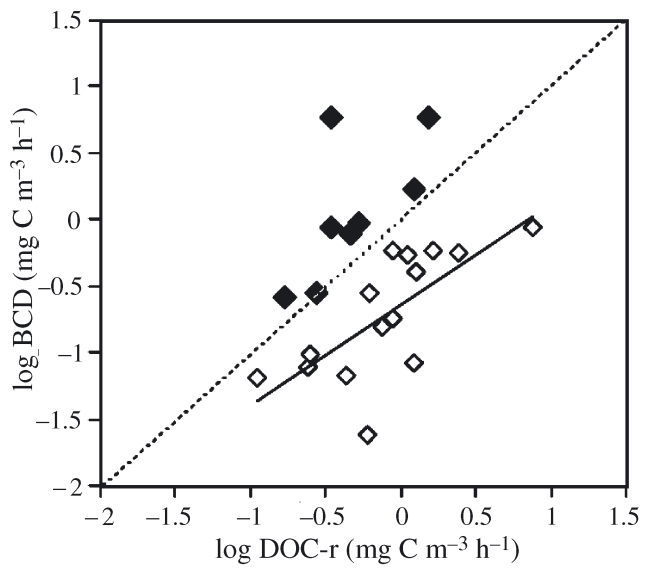

Fig. 5. Log-log relationship between estimated bacterial carbon demand (BCD) and dissolved organic carbon release (DOC-r). Dashed line: Slope 1; open symbols represent data below line of Slope 1; continuous line: corresponding regression $\left(\log [B C D]=0.75 \log [D O C-r]-0.64, r^{2}=0.50, p=0.0031\right.$, $\mathrm{n}=15)$

\section{Zooplankton biomass}

Mesozooplankton carbon biomass averaged 540 ( $\pm 144 \mathrm{SE}) \mathrm{mg} \mathrm{C} \mathrm{m}{ }^{-2}$ over the sampling period, with values ranging from 203 to $1576 \mathrm{mg} \mathrm{C} \mathrm{m}^{-2}$ (Table 1). A general increasing trend was observed from winter to summer, reaching a maximum during the decline in the productive period (September 1999). Zooplankton biomass represented on average $23 \pm 5 \%$ of total phytoplankton biomass, and ranged from 3 to $46 \%$, with maximum values at the end of summer and minimum values during winter and during the main upwelling event. Zooplankton biomass was also low, averaging $13 \pm 3 \%$ of total POC concentration throughout the sampling period.

\section{Microbial community respiration}

The vertical distribution of microbial community respiration (CR) as well as gross primary production (GPPo) and net community production (NCP) rates during the sampling period is shown in Fig. 6. A statistically significant log-log linear relationship was found between gross oxygen production (GPPo) (expressed in $\mathrm{mmol}_{2}$ ) and GPPC (in mmol C) rates, for both the volumetric and integrated datasets: $\log$ [GPPo] $=0.89$ $\log [\mathrm{GPPC}]+0.01\left(\mathrm{r}^{2}=0.63, \mathrm{p}<0.0001, \mathrm{n}=21\right) ;$ and $\log$ $[\mathrm{GPPo}]=0.94 \log [\mathrm{GPPC}]+0.17\left(\mathrm{r}^{2}=0.65, \mathrm{p}=0.0153\right.$, $\mathrm{n}=8)$, respectively. The average apparent photosynthetic quotient (PQ) obtained from the volumetric and integrated dataset was $1.40( \pm 0.28 \mathrm{SE})$ and 1.41 

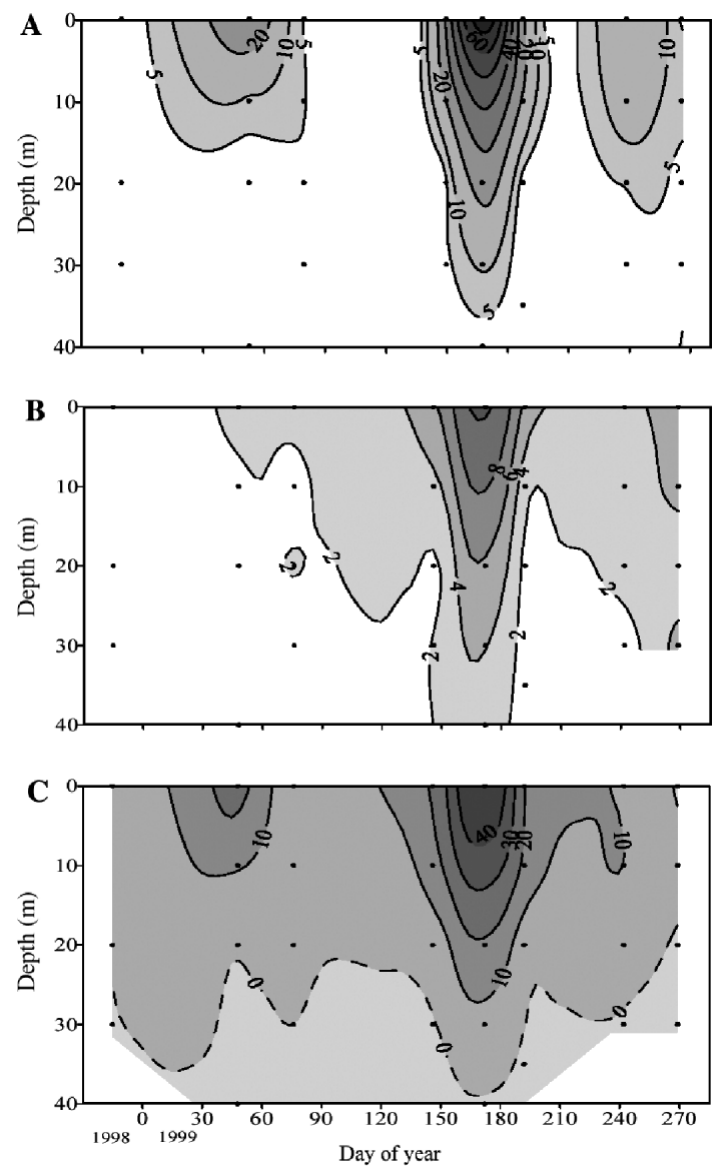

Fig. 6. Vertical distribution of (A) gross primary production of oxygen, (B) community respiration, and (C) net community production throughout sampling period. All are expressed as $\mathrm{mmol} \mathrm{O} \mathrm{m}^{-3} \mathrm{~d}^{-1}$

( $\pm 0.37 \mathrm{SE})$, respectively. The apparent PQ obtained by comparing NCP and GPPc was very low, averaging 0.86 ( $\pm 0.22 \mathrm{SE}$ ). According to Laws (1991), PQs for new and recycled production are estimated to be 1.4 and 1.1 , respectively. This indicates that our measurement of primary production (measured by ${ }^{14} \mathrm{C}$ uptake) is closer to gross than to net PP.

In general, CR decreased with increasing depth. Absolute rates of CR were globally higher from May (Day 145) to September (Day 271) 1999, with maximum values ranging from 5.7 to $13.1 \mathrm{mmol} \mathrm{O}_{2} \mathrm{~m}^{-3} \mathrm{~d}^{-1}$, and followed a very similar pattern to that of chlorophyll $a$ concentration during this productive period. The lowest values were measured in December 1998 (Day 350), when the rate of $\mathrm{CR}$ was $<1 \mathrm{mmol} \mathrm{O}_{2} \mathrm{~m}^{-3} \mathrm{~d}^{-1}$ within the entire euphotic zone. Euphotic-depth-integrated rates of CR ranged from 6 to $265 \mathrm{mmol} \mathrm{O}_{2} \mathrm{~m}^{-2} \mathrm{~d}^{-1}$, and from 70 to $3174 \mathrm{mg} \mathrm{C} \mathrm{m}^{-2} \mathrm{~d}^{-1}$ (Table 1). The microbial community exhibited an overall net autotrophic metabolism, as shown by the positive rates of NCP production measured throughout almost the entire euphotic zone
(Fig. 6). Negative NCP values were only measured at the limit of the euphotic zone. In September 1999 (Day 271), negative NCP values were found throughout the euphotic zone, except at $10 \mathrm{~m}$.

\section{Vertical particle flux}

The measured rates of exported POC from the euphotic zone off A Coruña ranged from 21 to 444 $\mathrm{mgC} \mathrm{m}{ }^{-2} \mathrm{~d}^{-1}$ (Table 2), which amounted to between 1 and $86 \%$ of GPPc. The high percentage measured in March 1999 could have resulted from sediment resuspension, although we have no conclusive evidence to confirm this.

\section{Production versus biogenic carbon losses}

The seasonal variability in daily euphotic-zone-integrated loss processes throughout the sampling period is presented in Fig. 7. Given that the main objective of the present investigation was to assess the significance of microbial-mediated carbon fluxes in relation to the herbivorous food chain, we have included as biogenic carbon losses both the carbon channelled via the microbial loop, either ending in $\mathrm{CO}_{2}(\mathrm{CR})$, accumulated DOC (DOC-a) or bacterial biomass (BP), as well as POC exported out of the photic layer (sinking carbon, SC). Accumulated DOC was estimated as the difference between $\mathrm{DOC}_{24 \mathrm{~h}}$ over $24 \mathrm{~h}$ and $\mathrm{BCD}$. The ratio between loss processes and production (\% L/P) was also calculated, and is presented in Fig. 7. As already mentioned, we took into account 2 possible

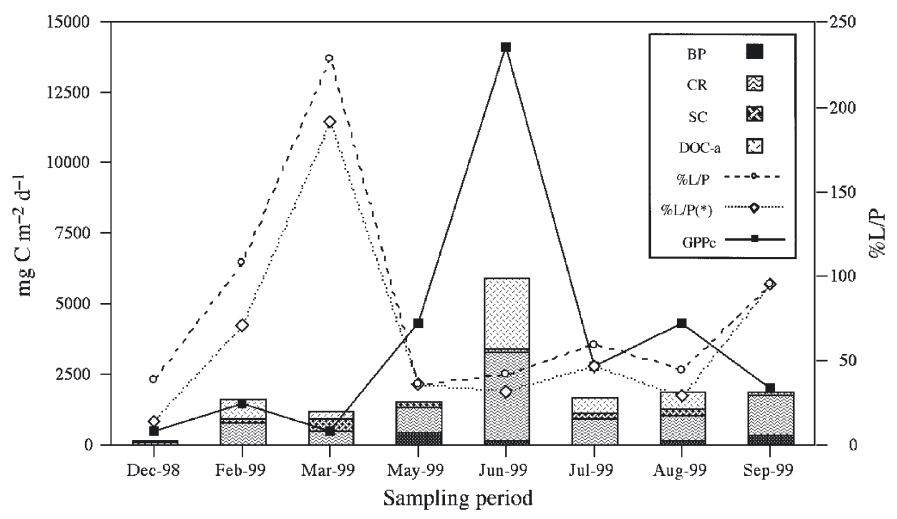

Fig. 7. Losses of biogenic carbon $\left(\mathrm{mgC} \mathrm{m}^{-2} \mathrm{~d}^{-1}\right)$ throughout sampling period, presuming constant DOC release over $24 \mathrm{~h}$. BP: bacterial production; CR: community respiration; SC: sinking carbon; DOC-a: DOC accumulated. Superimposed lines represent gross primary production $\left(\mathrm{GPPC}\right.$ as $\mathrm{mg} \mathrm{C} \mathrm{m}^{-2}$ $\mathrm{d}^{-1}$, and ratio between losses and GPPC $\left(\% \mathrm{~L} / \mathrm{P}, \% \mathrm{~L} / \mathrm{P}\left[{ }^{*}\right]\right.$, representing constant DOC release over $24 \mathrm{~h}$ or during light period only, respectively) 
values for DOC release; firstly we considered a constant release rate over the light period only, and secondly a constant release rate over a $24 \mathrm{~h}$ period. Consequently, we also calculated and represented the ratio between losses and production considering a constant DOC release rate over the light period only (\% L/P [ $\left.{ }^{*}\right]$ in Fig. 7). The difference between GPPC and the sum of carbon losses represents the maximum value of directly exportable biogenic carbon to higher trophic levels via the herbivore food web. Organic matter losses balanced or even exceeded production (\% L/P > 100) during early spring (February and March 1999) and during September 1999, assuming a constant DOC release over $24 \mathrm{~h}$. This situation would only occur in March and September 1999 if DOC were assumed to be produced during the light period only, and would arise from the combination of a very high fraction of primary production flowing through the DOC pool $(\geq 50 \%)$ and relatively high rates of microbial community respiration ( $>50 \%$ of GPPc). The relatively low contribution of bacterioplankton to the global microbial metabolism (BCD $<20 \%$ of GPPC) from December 1998 to March 1999 and from June 1999 to August 1999 resulted in a DOC accumulation ranging from 14 to $48 \%$ of GPPc. There was a surplus of biogenic carbon during December 1998 and during the late spring-summer period in 1999, with percentages of organic matter directly exportable through the herbivore food chain ranging from $40 \%$ (July 1999) to $64 \%$ (May 1999) of GPPC for a constant DOC release over $24 \mathrm{~h}$. On average, only $27 \%$ of the euphotic zone GPPC was directly available to higher trophic levels during the sampling period in this coastal system.

\section{DISCUSSION}

\section{Biomass distribution of plankton community}

The seasonal variation in oceanographic conditions and plankton biomass described in this study correspond to the typical annual cycle previously reported for this coastal area (e.g. Valdés et al. 1991, Casas et al. 1997, Bode \& Varela 1998). In general, the depthintegrated phytoplankton biomass during upwelling episodes in our study was higher than the phytoplankton biomass estimated during the summer upwelling off the Rías Baixas (e.g. Joint et al. 2001, Teira et al. $2001 \mathrm{~b}$ ). The bacterial biomass values we recorded are well within the range reported in the literature (see review by Valencia et al. 2003). Bacterial biomass remained relatively constant throughout the study, being always lower than phytoplankton biomass (Table 1). POC concentration was generally higher than the particulate carbon (integrated for 0 to $50 \mathrm{~m}$ depths) measured from May to June 1995 by Bode et al. (1998a) at the same station, and did not show variations in relation to phytoplankton biomass. The bacterial plus phytoplankton contribution to POC averaged $73 \%$, i.e. it is comparable to that in other coastal systems (e.g. Malone \& Ducklow 1990, Barquero et al. 1998). The contribution of phytoplankton biomass to POC was occasionally extremely high. This could have derived from the use of a constant C:chl a ratio (see 'Materials and methods') since it has been reported that this ratio falls to below 40 during upwelling conditions (see Varela et al. 1988). Unfortunately, we lack information on microzooplankton carbon biomass during the study period; however, in a previous study carried out on A Coruña continental shelf, Valdés et al. (1991), estimated that small grazers represented an average of $32 \%$ of total zooplankton biomass. Assuming this value to be typical for the area, the estimated microzooplankton biomass would represent only ca. $2 \%$ of the total POC. This low contribution of microzooplankton to total zooplankton biomass should be viewed with caution, given that samples within the 20 to $200 \mu \mathrm{m}$ size range did not include a considerable fraction of the microheterotrophic component (e.g. flagellates and ciliates). In addition, the relative contribution of microzooplankton to total zooplankton biomass can reach higher values (up to $55 \%$ ) during upwelling episodes (Bode \& Varela 1994). Although aware of the limitations of our calculations, we conclude that detrital particles are not a dominant fraction of the POC in this coastal station, in contrast with the results of Varela et al. (1988) and Barbosa et al. (2001) for Galician coastal waters.

Throughout the sampling period, average integrated mesozooplankton biomass was similar to that found by Bode et al. (1998b) for the same station between March and June 1995. The annual variations in zooplankton biomass closely followed the seasonal cycle described by Valdés et al. (1991) and Bode et al. (1998b) for A Coruña continental shelf, with minimum values during winter and higher concentrations in spring and summer. The main accumulation of zooplankton biomass took place in September 1999, following the high productivity period (from May to August 1999), when an average of more than $50 \%$ of GPPc was directly available to higher trophic levels.

The ratio of bacterial to phytoplankton stocks varied from 0.04 to 0.27 , with lowest values corresponding to upwelling episodes, as a consequence of the large accumulation of phytoplankton biomass. This range fits well within the very wide range reported by Ducklow (2000) for the marine environment. The averaged $\mathrm{BB} / \mathrm{PhB}$ ratio for the sampling period $(0.19 \pm 0.04)$ was in the upper limit of the typical range reported by Ducklow \& Carlson (1992) for coastal environments 
$(<0.2)$. This relatively high ratio between bacteria and phytoplankton standing stock provides some indication of the relevance of the microbial plankton system in this coastal area. Taking into account both the biomass of zooplankton and bacteria, the average ratio between heterotrophic biomass $(\mathrm{HB}=\mathrm{BB}+$ zooplankton biomass) and autotrophic biomass (PhB) was $0.4 \pm 0.1$. Considering that we have not included protozoa biomass in our study, the mean ratio we obtained is comparable to that reparted by Gasol et al. (1997) for coastal planktonic communities. Gasol et al. (1997) hypothesised that there is a tendency toward increasing planktonic $\mathrm{HB}: \mathrm{PhB}$ ratios from eutrophic to oligotrophic areas of the ocean. Accordingly, we could expect $\mathrm{HB}$ to exceed $\mathrm{PhB}$ under hydrographic conditions that lead to a limited supply of inorganic nutrients. This hypothesis is consistent with the results presented in this study, since situations with high $\mathrm{HB} / \mathrm{PhB}$ ratios (>0.5) corresponded to post-bloom stages. Barquero (1999) derived the same conclusion from nitrogen recorded balances at the same station in a previous sampling period.

\section{Carbon flow through plankton community: importance of microbial food web}

Maximum integrated primary production in the coastal system studied was found during summer upwelling (June 1999, Table 2); it was the highest rate ever reported for these waters (see Valencia et al. 2003). Apart from this extremely high value, the integrated GPPc rates obtained from May to September were close to those measured by Teira et al. (2001a) off the Rías Baixas during summer 1998, under upwelling conditions.

The relatively low percentage of variability in DOC release explained by POC production (Fig. 4) suggests the importance of microbial trophic processes as DOC sources (Teira et al. 2001a,b). On average, DOC release (for a constant release over a $24 \mathrm{~h}$ period) accounted for $37 \pm 7 \%$ of euphotic-depth-integrated $\mathrm{GPPC}_{\mathrm{C}}$ and the highest percentages were measured during low-productivity periods (December 1998 to March 1999, and September 1999). This average value was notably higher than previous measurements in highly productive coastal systems (Teira et al. 2001a,b, and references therein). It is important to bear in mind that these previous studies provided data for relative DOC release with a constant flow of dissolved substances during the light period only. We hypothesise that such data would only be valid if phytoplankton extracellular release depended exclusively on photosynthetic rate. As discussed by Teira et al. (2001a), this would correspond to phytoplankton growing exponen- tially under culture conditions and, consequently, free from stress factors and grazing pressure, whereas under natural conditions a joint effect of physiological and trophic processes implied by the DOC release of microbial communities would be expected. We suggest that if this process occurs only during the light period, then DOC release could be underestimated and the resulting bias would increase with increasing importance of trophic processes within the microbial community. If DOC release occurred only during the light period (on average $15 \pm 2 \%$ of GPPC), then an average BCD would comprise $254 \%$ of DOC release, and large allochthonous inputs of DOC would be necessary. This would contrast with the measured net autotrophic microbial metabolism whereby globally, only $40 \%$ of GPPc is respired by the microbial community. The high relative DOC release rate measured in February (60\%) and September (50\%) 1999, despite GPPC rates of $>1.4$ $\mathrm{g} \mathrm{C} \mathrm{m}^{-2} \mathrm{~d}^{-1}$, could reflect an early stage in the decline of a phytoplankton bloom.

Bacterial production in this coastal zone was low in comparison with that in other aquatic ecosystems (Valencia et al. 2003, and references therein). The constancy of bacterial biomass despite the variability in BP rates suggests that bacterial stocks are limited principally by removal processes (Pace \& Cole 1996), thus presumably contributing to the conventional metazoan food web. We estimated BGE and BCD using the empirical model of Rivkin \& Legendre (2002), which relates BGE with water temperature. The estimated BR represented an average of $60 \%$ of total community respiration, which lies within the range of values derived from size-fractionated respiration measurements (Robinson et al. 1999, Sherry et al. 1999, review: Williams 2000). The DOC supply of microplankton was sufficient to support the estimated BCD, except in May and September 1999. From December 1998 to March 1999 and from June to August 1999, DOC release greatly exceeded bacterial consumption, thus leading to the accumulation of semi-labile DOC in the upper layer. This could explain the high rates of bacterial metabolism (exceeding DOC release rates) in May and September 1999. Lateral advection could have also contributed to these high BCD rates, although we do not have any data to support this. Enhanced DOC concentrations in the euphotic layer after a phytoplankton bloom have previously been reported (e.g. Brussaard et al. 1996, Packard \& Chen 2000), and it has been suggested that this temporal shift between DOC production and consumption could explain the heterotrophic balance in temperate coastal ecosystems during the stratified period (Blight et al. 1995, Sherr \& Sherr 1996, Serret et al. 1999). The uncoupling between phytoplankton and bacteria is reflected in the lack of a relationship between BCD and DOC release. This rela- 
tionship becomes statistically significant once all data pairs corresponding to $\mathrm{BCD}>\mathrm{DOC}$ are removed, with $50 \%$ of the observed variability in $\mathrm{BCD}$ rates being explained by concurrent DOC release.

It is well known that carbon budgets, as calculated in the present work, are mainly sensitive to changes in BGE (Van Wambeke et al. 2002). For this reason, we tested how different estimates or values of BGE could affect the carbon budget. We discarded the use of the empirical model of del Giorgio \& Cole (1998) to estimate BGE, because the application of this equation would overestimate BR to such an extent that it would even exceed total CR. We also calculated BCD using BGE values of 10 and $30 \%$ as an alternative to the average $22 \%$ obtained with the model of Rivkin \& Legendre (2002). When a value of $10 \%$ was used, rates of BR also greatly exceeded total CR. Assuming a $30 \%$ value for BGE resulted in a BR equivalent to $40 \%$ of $\mathrm{CR}$, which is also in accordance with values reported in the literature. However, the \% L/P derived from a BGE of $30 \%$ differed by $9 \%$ from that calculated using BGE values derived from the empirical model of Rivkin \& Legendre (2002).

We observed a good relationship between CR/GPPC and DOC/GPPC ratios. The higher these ratios, the less biogenic carbon will be directly available to the herbivorous food chain. Consequently, they can be considered as good indicators of the importance of microbial trophic processes in planktonic systems. In contrast, due to the temporal uncoupling between bacteria and phytoplankton, we did not find a good relationship between $\mathrm{BP} / \mathrm{GPPC}$ or $\mathrm{BCD} / \mathrm{GPPC}$ ratios and the fraction of primary production directly accessible to higher trophic levels. This observation is in accordance with the findings of Van Wambeke et al. (2002), who also concluded that the ratio between BP and PP did not provide a clear understanding of the importance of biological processes in the cycling of carbon in the upper water column.

In conclusion, we have shown that microbial processes play an important role in the carbon cycling of this coastal ecosystem mainly during low productivity periods. Our data support the notion that, contrary to traditional paradigms, small autotrophs contribute significantly to production and are actively incorporated into the microbial food web in shelf ecosystems (Verity et al. 2002). Taking into account that an average of $15 \%$ of primary production was lost as sinking carbon, $40 \%$ was respired within the microbial community, $6 \%$ accumulated as BB and $11 \%$ accumulated as DOC, only $28 \%$ of GPPc was directly available to higher trophic levels in the plankton ecosystem off A Coruña during the sampling period, whereas an average of $57 \%$ GPPC was processed by the microbial community, thus emphasising the importance of the microbial food web in this planktonic system. Only during the high productivity period, from May to August 1999, did the classic food chain acquire relevance, when an average of $52 \%$ of GPPC was directly available to higher trophic levels.

Acknowledgements. We are grateful to the crew of the RV 'Lura' for their assistance during sampling. We would also like to express our thanks to B. Castro for help in processing and counting bacterial samples, and to P. Iglesias and M. Fermoso for their assistance in processing the plankton and chemical samples. Wind data was provided by the Centro Metorológico Zonal de A Coruña, Instituto Nacional de Meteorología (Spain). This research was supported by the project XUGA-10302B98 of the Xunta de Galicia (Spain), and by funds of the Instituto Español de Oceanografía (project IEO-1007). E.T. was supported by a PFPI fellowship from the Ministerio de Educación y Cultura (Spain).

\section{LITERATURE CITED}

Álvarez-Salgado XA, Castro CG, Pérez FF, Fraga F (1997) Nutrient mineralization patterns in shelf waters of the Western Iberian upwelling. Contin Shelf Res 17:1247-1270

Bakun A (1973) Coastal upwelling indices, west coast of North America, 1946-1971. NOAA Tech Rep NMFS SSRP-671

Barbosa AB, Galvao HM, Mendes PA, Álvarez-Salgado XA, Figueiras FG, Joint I (2001) Short-term variability of heterotrophic bacterioplancton during upwelling off the NW Iberian margin. Prog Oceanogr 51:339-360

Barlow RG, Mantoura RFC, Cummings DG, Pond DW, Harris RP (1998) Evolution of phytoplankton pigments in mesocosm experiments. Estuar Coast Shelf Sci 46(Suppl A): $15-22$

Barquero S (1999) Regeneración de nutrientes como control de la producción primaria planctónica por los heterótrofos. $\mathrm{PhD}$ thesis, Universidad de Oviedo, Spain

Barquero S, Botas JA, Bode A (1998) Abundance and production of pelagic bacteria in the southern Bay of Biscay during summer. Sci Mar 62:83-90

Biddanda B, Ogdahl M, Cotner J (2001) Dominance of bacterial metabolism in oligotrophic relative to eutrophic waters Limnol Oceanogr 46:730-739

Blanton JO, Atkinson LP, Castillejo FF, Lavín A (1984) Coastal upwelling off the Rías Bajas, Galicia, northwest Spain. I. Hydrographic studies. Rapp p-v Réun Cons Int Explor Mer 183:79-90

Blight SP, Bentley TL, Lefevre D, Robinson C, Rodrigues R, Rowlands J, Williams PJ leB (1995) Phasing of autotrophic and heterotrophic plankton metabolism in a temperate coastal ecosystem. Mar Ecol Prog Ser 128:61-75

Bode A, Varela M (1994) Planktonic carbon and nitrogen budgets for the N-NW Spanish shelf: the role of pelagic nutrient regeneration during upwelling events. Sci Mar 58:221-231

Bode A, Varela M (1998) Primary production and phytoplankton in three Galician Rias Altas (NW Spain): seasonal and spatial variability. Sci Mar 62:319-330

Bode A, Casas B, Fernández E, Marañón E, Serret P, Varela M (1996) Phytoplankton biomass and production in shelf waters off NW Spain: spatial and seasonal variability in relation to upwelling. Hydrobiologia 341:225-234

Bode A, Varela M, Barquero S (1998a) Preliminary studies on the export of organic matter during phytoplankton blooms 
off La Coruna (north-western Spain). J Mar Biol Assoc UK 78:1-15

Bode A, Álvarez-Ossorio MT, González N (1998b) Estimations of mesozooplankton biomass in a coastal upwelling area off NW Spain. J Plankton Res 20:1005-1014

Brussaard CPD, Gast GJ, van Duyl FC, Riegman R (1996) Impact of phytoplankton bloom magnitude on a pelagic microbial food web. Mar Ecol Prog Ser 144:211-222

Casas B (1995) Composición, biomasa y producción del fitoplancton en la Costa de La Coruña. PhD thesis, Universidade de Santiago de Compostela, Spain

Casas B, Varela M, Canle M, González N, Bode A (1997) Seasonal variations of nutrients, seston and phytoplankton, and upwelling intensity off La Coruña (NW Spain). Estuar Coast Shelf Sci 44:767-778

Castro CG, Álvarez-Salgado XA, Figueiras FG, Pérez FF, Fraga F (1997) Transient hydrographic and chemical conditions affecting microplankton populations in the coastal transition zone of the Iberian upwelling system (NW Spain) in September 1986. J Mar Res 55:321-352

Cole JJ, Pace ML, Findlay S (1988) Bacterial production in fresh and saltwater ecosystems: a cross-system overview. Mar Ecol Prog Ser 43:1-10

del Giorgio PA, Cole JJ (1998) Bacterial growth efficiency in natural aquatic systems. Annu Rev Ecol Syst 29:503-541

del Giorgio PA, Cole JJ (2000) Bacterial energetics and growth efficiency. In: Kirchman DL (ed) Microbial ecology of the oceans. Wiley-Liss, New York, p 289-326

Ducklow HW (1999) The bacterial component of the oceanic euphotic zone. FEMS Microbiol Ecol 30:1-10

Ducklow HW (2000) Bacterial production and biomass in the oceans. In: Kirchman DL (ed) Microbial ecology of the oceans. Wiley-Liss, New York, p 85-120

Ducklow HW, Carlson CA (1992) Oceanic bacterial production. Adv Microb Ecol 12:113-181

Estrada M (1984) Phytoplankton distribution and composition off the coast of Galicia (northwest of Spain). J Plankton Res 6:417-434

Fogg GE (1983) The ecological significance of extracellular products of phytoplankton photosynthesis. Bot Mar 26: $3-14$

Fraga F (1981) Upwelling off the Galicia coast, NW Spain. In: Richard FA (ed) Upwelling ecosystems. American Geographical Union, Washington, DC, p 176-182

Gasol JM, del Giorgio PA, Duarte CM (1997) Biomass distribution in marine planktonic communities. Limnol Oceanogr 42:1353-1363

Gasol JM, Doval MD, Pinhassi J, Calderón-Paz JI, GuixaBoixareu D, Vaqué D, Pedrós-Alió C (1998) Diel variations in bacterial heterotrophic activity and growth in the northwestern Mediterranean Sea. Mar Ecol Prog Ser 164: 107-124

Grasshoff K, Ehrhardt M, Kremling (1983) Methods of seawater analysis, 2nd edn. Verlag Chemie, Weinheim

Hoppe HG, Gocke K, Koppe R, Begler C (2002) Bacterial growth and primary production along a north-south transect of the Atlantic Ocean. Nature 416:168-171

Joint I, Rees AP, Woodward EMS (2001) Primary production and nutrient assimilation in the Iberian upwelling in August 1998. Prog Oceanogr 51:303-320

Kirchman DL (1993) Leucine incorporation as a measure of biomass production by heterotrophic bacteria. In: Kemp PF, Sherr BF, Sherr EB, Cole JJ (eds) Handbook of methods in aquatic microbial ecology. Lewis Publishers, Boca Raton, FL, p 509-512

Kirchman DL, Ducklow HW (1993) Estimating conversion factors for the thymidine and leucine methods for measuring bacterial production. In: Kemp PF, Sherr BF, Sherr EB, Cole JJ (eds) Handbook of methods in aquatic microbial ecology. Lewis Publishers, Boca Raton, FL, p 513-517

Knauer GA, Martin JH, Bruland KW (1979) Fluxes of particulate carbon, nitrogen and phosphorus in the upper water column of the northeast Pacific. Deep-Sea Res 26:97-108

Lavin A, Díaz del Río G, Casas G, Cabanas JM (2000) Afloramiento en el Noroeste de la Península Ibérica: índices de afloramiento para el punto $43^{\circ} \mathrm{N}, 11^{\circ} \mathrm{O}$-Periodo 1990-1999. Datos Resúmenes Inst Esp Oceanografía 15: $1-25$

Laws EA (1991) Photosynthetic quotients, new production and net community production in the open ocean. DeepSea Res 38:143-167

Legendre L, Le Fèvre J (1995) Microbial food webs and the export of biogenic carbon in oceans. Aquat Microb Ecol 9:69-77

Longhurst A (1995) Seasonal cycles of pelagic production and consumption. Prog Oceanog 36:77-167

Malone TF, Ducklow HW (1990) Microbial biomass in the coastal plume of Chesapeake Bay: phytoplankton-bacterioplankton relationships. Limnol Oceanogr 35:296-312

Nagata T (2000) Production mechanisms of dissolved organic matter. In: Kirchman DL (ed) Microbial ecology of the oceans. Wiley-Liss, New York, p 121-152

Norland S, Heldal M, Tumyr O (1987) On the relation between dry matter and volume of bacteria. Microb Ecol 13:95-103

Pace ML, Cole JJ (1996) Regulation of bacteria by resources and predation tested in whole-lake experiments. Limnol Oceanogr 41:1448-1460

Packard T, Chen W, Blasco D, Savenkoff C and 9 others (2000) Dissolved organic carbon in the Gulf of St. Lawrence. Deep-Sea Res 47:435-460

Porter KG, Feig YS (1980) The use of DAPI for identifying and counting aquatic microflora. Limnol Oceanogr 25:943-948

Rivkin RB, Legendre L (2002) Biogenic carbon cycling in the upper ocean: effects of microbial respiration. Science 291: $2398-2400$

Robinson C, Archer S, Williams PJ leB (1999) Microbial dynamics in coastal waters of east Antarctica: plankton production and respiration. Mar Ecol Prog Ser 180:23-36

Serret P, Fernández E, Sostres JA, Anadón R (1999) Seasonal compensation of microbial production and respiration in a temperate sea. Mar Ecol Prog Ser 187:43-57

Sherr EB, Sherr BF (1996) Temporal offset in oceanic production and respiration processes implied by seasonal changes in atmospheric oxygen: the role of heterotrophic microbes. Aquat Microb Ecol 11:91-100

Sherry ND, Boyd PW, Sugimoto K, Harrison PJ (1999) Seasonal and spatial patterns of heterotrophic bacterial production, respiration, and biomass in the subarctic NE Pacific. Deep-Sea Res II 46:2557-2578

Shiah FK, Chen TY, Gong GC, Chen CC, Chiang KP, Hung JJ (2001) Differential coupling of bacterial and primary production in mesotrophic and oligotrophic systems of the East China Sea. Aquat Microb Ecol 23:273-282

Smith DC, Azam F (1992) A simple, economical method for measuring bacterial protein synthesis rates in seawater using ${ }^{3} \mathrm{H}$-leucine. Mar Microb Food Webs 6:107-114

Straskraba M, Gnauck AH (1985) Freshwater ecosystems: modelling and simulation. Elsevier, Amsterdam

Teira E, Pazó MJ, Serret P, Fernández E (2001a) Dissolved organic carbon (DOC) production by microbial populations in the Atlantic Ocean. Limnol Oceanogr 46:1370-1377

Teira E, Serret P, Fernández E (2001b) Phytoplankton sizestructure, particulate and dissolved organic carbon production and oxygen fluxes through microbial communities 
in the NW Iberian coastal transition zone. Mar Ecol Prog Ser 219:65-83

Tenore KR, Alonso-Noval M, Álvarez-Ossorio M, Atkinson LP and 15 others (1995) Fisheries and oceanography off Galicia, NW Spain: mesoscale spatial and temporal changes in physical processes and resultant patterns of biological productivity. J Geophys Res 100:10943-10966

Uitto A, Heiskanen AS, Pajuniemi R (1997) Summer dynamics of the coastal planktonic food web in the northern Baltic Sea. Mar Ecol Prog Ser 151:27-42

Valdés L, Álvarez-Ossorio MT, Lavín A, Varela M, Carballo R (1991) Ciclo anual de parámetros hidrográficos, nutrientes y plancton en la plataforma continental de La Coruña (NO, España). Bol Inst Esp Oceanogr 7:91-138

Valencia J, Abalde J, Bode A, Cid A and 5 others (2003) Variations in planktonic bacterial biomass and production, and phytoplankton blooms off A Coruña (NW Spain). Sci Mar 67:143-157

Editorial responsibility: Otto Kinne (Editor),

Oldendorf/Luhe, Germany
Van Wambeke F, Heussner S, Diaz F, Raimbault P, Conan P (2002) Small-scale variability in the coupling/uncoupling of bacteria, pytoplankton and carbon fluxes along the continental margin of the Gulf of Lions, northwestern Mediterranean Sea. J Mar Syst 33-34:411-429

Varela M, Álvarez-Ossorio MT, Valdés L, Cal R, Miranda A, de Santiago G, Costas E (1988) Partición de la materia orgánica particulada en el área de afloramiento de la plataforma de Galicia (NO de España) durante la campaña BREOGAN 684. Bol Inst Esp Oceanogr 5:97-108

Verity PG, Redalje DG, Lohrenz SR, Flagg C, Hristov R (2002) Coupling between primary production and pelagic consumption in temperate ocean margin pelagic ecosystems. Deep-Sea Res II 49:4553-4569

Williams PJ leB (2000) Heterotrophic bacteria and dynamics of dissolved organic material. In: Kirchman DL (ed) Microbial ecology of the oceans. Wiley-Liss, New York, p 153-200

Submitted: December 5, 2002; Accepted: September 9, 2003 Proofs received from author(s): December 8, 2003 